\title{
STUDENT'S READING COMPREHENSION OF DIFFERENT GENRES IN SMP NEGERI 2 PANCURBATU
}

\author{
By: \\ Puan Suri Mira Annisa ${ }^{1)}$ \\ Bahagia Saragih $^{2)}$ \\ Universitas Negeri Medan ${ }^{1,2)}$ \\ E-mail: \\ puansuri19@gmail.com ${ }^{1)}$ \\ gyabucks123@gmail.com $^{2)}$
}

\begin{abstract}
This study aims at (1) finding out the level of students reading comprehension of different genres and (2) describing students reading comprehensionof different genres of text. The subject of the research is the eighth grade students in SMP Negeri 2 Pancurbatu. The research was conducted by using descriptive qualitative method. The data were collected by using reading comprehension test and interview. Then he data were analyzed by identifying the result of test first, describing the result and the last was explaining the result. Based on the result of the data analysis, it was found that the students are good at both literal and inferrential. Literal comprehension is $75.95 \%$ better than inferrential 1comprehension $72,68 \%$. Furthermore, students reading comprehension of narrative texts is the dominant genre with $75.00 \%$ which belonged to good category and followed by recount text with $72.98 \%$, procedure text with $73.79 \%$ and the last is descriptive text with $69.75 \%$ which the only genre belonged to fair category.
\end{abstract}

Keywords:Reading Comprehension, Genre of Text

\begin{abstract}
ABSTRAK
Penelitian ini bertujuan untuk (1) menemukan tingkat kemampuan siswa dalam membaca text dengan genre yang berbeda dan (2) mendeskripsikan kemampuan siswa dalam membaca. Subjek penelitian merupakan siswa tingkat delapan di SMP Negeri 2 Pancurbatu. Metode penelitian ini menggunakan Deskriptif kualitatif. Pengumpulan data menggunakan Tes membaca teks dan wawancara. Kemudian data di analisa berdasarkan hasil dari tes pertama, menggambarkan hasil dan yang terakhir penjelasan dari hasil. Berdasarkan hasil analisis siswa menguasai dalam hal membaca literal dan inferential. Dalam membaca literal $75.95 \%$ sangat baik dbandingkan membaca inferential $72.68 \%$. Siswa sangat dominan dalam membaca Genre Narrative text $75.00 \%$, kemudian Recount Text $72.98 \%$, Procedure Text $73.79 \%$ dan Descriptive Text $69.75 \%$.
\end{abstract}

Kata Kunci: Membaca, Genre dari Teks

\section{Introduction}

Reading is an important skill in our daily life because it can give so many advantages for us. In learning
English, being able to comprehend reading passage is a must. When the teacher gives text for the students to answer some questions, they possibly 
cannot answer it well if they do not comprehend reading passage well. Klinger (2007:2) states reading comprehension is the process of constructing meaning by coordinating a number of complex process including word reading, word and world knowledge and fluency. It refers to ability to an ability in interprating the words understanding the meaning and the relationships between ideas conveyed in a text. It's mean that the ability of the readers to understand what they are reading; interpret ideas and inject meaning to printed words is comprehension. Thus, reading alone is not enough; there must be comprehensionso that learners may not only focus on the text but also on the interpretation of its deeper meanings.

The importance of reading comprehension is emphasized in the education community. Students have to use reading skills in every single subject they ever study and in almost every aspect of life. As a student, people who can read comprehensively, can also be successful in all his/her lessons. In other hand, peoples who talks about reading comprehension he also must be know about genre. Genre is related to all skill of language. Genre in English text is meant to be determinative to the form of language. Genre plays an important role to construct the conceptual meaning of the readersfrom a text. Therefore the good understanding of genre is considered as a vital to findout what the expected meaning in a text. In education, for instance, students are expected to be familiar with genre and good at identifying and applying it in getting information from a reading text, since the knowledge and skills will be useful fortheir future jobs or higher education.

Siwa (2015) finds that the students' reading comprehension has a positive correlation with students' ability to identify genre text in learning reading. It was proved by the result of correlation coefficient that showed correlation between the students' reading comprehension and the ability to identify genre in learning reading is very significant. It means that by having good reading comprehension, the students' have opportunity to increase their knowledge to identify genre text.

To make this research, as a researcher must get a gap before take a data.So,a preliminary data was done to get information about the practice of English language teaching at SMP Negeri 2 Pancurbatu by the researcher. It is carried out on 16 January 2020 by interviewing the English teacher Ade Irma Suryani. Based on her explanation, the school is applying Institutional Based Curriculum and using English Focused as a textbook and worksheet for teaching learning process. She also informed that she had never test the student's ability based on each skill. However, she tested the English skill integrated with other skill. As a result, she does not know the student's skill especially in reading skill. She also said that she had never measure the students reading comprehension skill based on 
text genre. So, the researcher used students English score from DKN (Daftar Kumpulan NIlai) as the preliminary data. Based on the background of the study above, it is important to identify the research problem. They are (1) To what level do students comprehend texts of different genres? And (2) Howis students reading comprehension of texts of different genres?

The scope of this study is focused on reading comprehension of text type or genre of reading descriptive, narrative text, recount text andprocedure text and the findings are expected to give some contributions that the future researcher may be use it as the references to conduct another research or students may be able to determine their reading performance and may evaluate their strengths and weaknesses on reading.

\section{A. Riview of literatures}

According to summer (1999:15), reading comprehension means understanding and remembering the ideas you fine as you read. Meanwhile, Snow at al (2002) define reading comprehension as a process of stimultanneously extracting and constructing meaning trough interaction and involvement with written language. Morever, Klinger (2007:2) who states that reading comprehension is the process of constructing meaning by coordinating a number of complex process including word reading, word and world knowledge and fluency. It refers to ability tointerperate the words understanding the meaning and the relationships between ideas conveyed in a text. From both point of view, researcher concluded that reading comprehension as a complex process of constructing meaning by coordinating number of skills as related to decoding, word reading, fluency the integration of background knowledge, vocabulary and previous experiences.

Klinger et al (2007:8) describe five basic comprehension processes that work together simultaneously and complement one another: microprocesses, integrative processes, macroprocesses, elaborative processes, and metacognitive processes. Furthermore Brassel (2008:17) in his book states that there are three level of reading comprehension. The three taxonomy of Brassel are literal, inferential and critical comprehension. All three levels of comprehension are important and need to be fostered. However, it has been said in chapter I junior highschool students is only taught to understand the first and the second level of reading comprehension.

However, Klinger (2007:18) states that reading comprehension measures should help teachers monitor the comprehension of their students over time and provide information that is useful in designing reading comprehension intervention programs. When assessing comprehension it is important that the material students are asked to read is at their instructional level (rather than frustration level) and 
that they can read the passage with adequate fluency. Gunning (2002) says if the student cannot read at least $95 \%$ of the words, comprehension will be hampered. Similarly, if the student is a slow, laborious reader (though accurate), comprehension will suffer.

Furthermore, knowing the genre and its rules helps the readers to make reasonable guesses at how a text is likely to be read by audiences. By knowing the genre, automatically the readers will have a sense and it is a feeling to guess, and then understand how the genre works. The study of genre is important because it provides the readers the insights about what texts should be like, how they are created, and how they have function for the readers. Based on the definition above, the researcher conclude that genre was important in reading comprehension and toproved it researcher describe some types of texts which are describing, narrating and instructing.

Mayer in Klinger (2007) states that when the reader or students are familiar with the way a text is structured, this knowledge can help them form expectations about what they will read, organize incoming information, judge the relative importance of what they read, improve their comprehension, and enhance their recall.However, when the structure of a text is different from what the reader expects, comprehension can break down. Struggling readers are more likely than stronger readers to be unaware of text structures and to experience difficulty using them to help with comprehension. Yet explicit instruction can help struggling readers become more aware of various text structures and augment their comprehension and memory.

There are some researches have been done by several researchers, the first was Ammrus's(2015) A descriptive study on the eighth grade student's reading comprehension achievement of recount text at SMP N 2 Banyuwangi, Aminah(2017) conducted a reasearch about An analysis of students' difficulties in reading comprehension on narrative text, Tizon (2013)onReading comprehension ability of grade vi pupils of Kinangaysur Elementary School, and another researches that analyses reading comprehension.

\section{B. Research methodology}

According to Ary (2010) descriptive research is studies thatdesigned to obtain information concerning the current status phenomena.In this study the researcher describedstudents'reading comprehension of texts of different genres. In this case the researcher will use the designdescriptive qualitative research. This research was conductedto describe students reading comprehension of text of different genres. It focusedon descriptive, narrative, recount and procedure text. In order to get the data collection, the researcher conducted the test in the classroom and took60 minutes as the 
source of the data.The source of the data in this researchwas student's reading comprehension of text of different genres score. The population of the research werethe eighth grade junior high school students of SMP Negeri 2 Pancurbatu.In this research the researcher collected the data by tryout, test, interview and document.

\section{Data Analysis, Finding, and Discussion}

The test was administered on Feb12th 2020. The researcherchose one of the classes purposively by doing lottery to decide which class wasused for test. Thus, the subjects of the try out were VIII 1 class. The VIII 1 class, consisted of 35 students. The researcher constructed 40 the reading test items in the form ofmultiple choice models with four options. The multiple choice model was applied in this research because it was easy and practically to score. The test items wereaimed to measure the students' reading comprehension of text of different genres. The students were able to accomplish the reading comprehensionachievement test for about 75 minutes.

In order to find out the extent to which the samples are able to comprehend the text in two categories, they are (1) Literal reading comprehension (2) Inferential reading comprehension. The result was:

\begin{tabular}{|c|c|c|c|c|}
\hline No & Indicators & The percentage & Category & Interval \\
\hline 1 & Literal & 75.95 & Good & $70-79$ \\
\hline 2 & Inferential & 72.41 & Good & $70-79$ \\
\hline \multicolumn{2}{|c|}{$\begin{array}{c}\text { Students Reading } \\
\text { Comprehension }\end{array}$} & 73.95 & Good & $70-79$ \\
\hline
\end{tabular}

It presents the percentage of the students' test in readingcomprehension text of different genresin level of literal and inferential comprehension. Thehighest percentage of the level was literal comprehension with thepercentage of $75.95 \%$ which belonged to the "good" category. It meant that $75.95 \%$ the students got the scores between 80-100. Then, the percentage of the inferential comprehension was $72.68 \%$ which was also categorized "good". From the indicators, it can be stated that literal comprehension and inferential comprehension was classified in"good" category.

\begin{tabular}{|c|c|c|c|c|}
\hline No & Genres & The percentage & Category & Interval \\
\hline 1 & Descriptive & 69.75 & Fair & $60-69$ \\
\hline 2 & Narrative & 75.00 & Good & $70-79$ \\
\hline
\end{tabular}




\begin{tabular}{|c|c|c|c|c|}
\hline 3 & Recount & 72.98 & Good & $70-79$ \\
\hline 4 & Procedure & 73.79 & Good & $70-79$ \\
\hline Students Reading Comprehension & 73.29 & Good & $70-79$ \\
\hline
\end{tabular}

Narrative text with the percentage of $75 \%$ which belonged to the "good" category. It meant that $75 \%$ the students got the scores between 70-79. Then, the percentage of procedure text was $73.29 \% \%$ which was categorized "good" the students got the score between 70 - 79. The percentage of recount text was $72.98 \%$ which was also categorized as "good". The last was descriptive text comprehension with the percentage $69.75 \%$ which was classified as "fair". From the four genres, it can be stated that narrative text comprehension, recount text comprehension, and procedure text comprehension was classified in "good" category, only descriptive text comprehension was classified "fair" category with percentage $69.75 \%$.

From the explanation above, it can be concluded that the eighth grade students SMP Negeri 2 Pancurbatu has good achievement in reading comprehension of text of different genres because the average of the two level were classified as "good" category with percentage $73.95 \%$ which belonged to interval 70-79.

From the interview, the English teacher taught reading comprehension used lecturing and discussing. Before she started the lesson, he activated the students by giving leading questions about the previous lessons. Then, she gave explanation to the students. After the explanation to the students, she asked the students to do the exercises and finally, discussed the answer with the whole class. It was also known that he used English materials based on 2006 Institutional-

$$
\text { Based Curriculum to teach }
$$
English on grade VIII class at SMPN 2 Pancurbatu. The material used in the teaching and learning process was English text book entitled "Let's Talk" (by JokoSiswantoet al, published in 2005) and students' worksheet entitled "English Assessment Text" (by NurZaida, published in 2010) and from the internet. The teacher used worksheet as the supplementary book and used the exercises in worksheet as homework for the students and discussed the answer in the following meeting.

From the interview, the English teacher taught reading comprehension used lecturing and discussing. Before she started the lesson, he activated the students by giving leading questions about the previous lessons. Then, she gave explanation to the students. After the explanation to the students, she asked the students to do the exercises and finally, discussed the answer with the whole class. It was also known that he used English materials based on 2006 Institutional- 
Based Curriculum to teach English on grade VIII class at SMPN 2 Pancurbatu. The material used in the teaching and learning process was English text book entitled "Let's Talk" (by JokoSiswantoet al, published in 2005) and students' worksheet entitled "English Assessment Text" (by NurZaida, published in 2010) and from the internet. The teacher used worksheet as the supplementary book and used the exercises in worksheet as homework for the students and discussed the answer in the following meeting.

Based on the discussion above, in summary it was revealed that the reading comprehension text of different genres of the eighth grade students of SMPN 2 Pancurbatu belonged in "good" category level. Because average of the students from 30 students had good achievement in reading comprehension.

\section{Conlusion}

After analyzing the data on the research finding and discussion, the conclusion of the present study can be drawn as follows:(1) Eighth grade students of SMPN2 Pancurbatu comprehend texts of different genres in level of literal and inferential comprehension.Eighth grade students of SMPN2 Pancurbatu's reading comprehension of texts of different genres is good category (72.41). Then, forliteral comprehension is 75.95 which belong to good category and inferential comprehension is 72.41 also belong to good category. It shows eighth grade students of SMPN2 Pancurbatu has better literal comprehension than inferential comprehension and (2) Eighth grade students of SMPN2 Pancurbatu comprehend texts of 4 different genres. They are descriptive 69.75 which is belong to fair category, narrative 75 , recount 73.98 and procedure 73.29 are belong to good category. It shows eighth grade studentsof SMPN2 Pancurbatu comprehend narrative text better than others. Even though based on the result, students reading comprehension of texts of different genres is categorized as good comprehension.

\section{REFERENCES}

Ary, Donald. 2010. Introduction to Research in Education. Belmont: Nelsson Education

Cresswell, J. 2014. Research Design : Qualitative, Quantitative, and Mixed Methods Approaches. California: Sage Publication

Siwa,Hasriani.2015.Correlation between the Students Reading Comprehension and the Ability to Identify Genre in Reading.Universitas Negeri Gorontalo.

Klingner,Janette K., Vaughn, Sharon., Boardman,Alison. 2007. Teaching Reading Comprehension to Students with Learning 
Difficulties.New York: The Guilford Press.

Snow, Catherine. 2002. Reading for Understanding.Santa Monica:

Knapp, Peter and Watkins, Megan. RAND

2005. Genre, Text

GrammarTechnologies for

Teaching and Assesing Writing.Sydney:A UNSW Press Book

McKee, Alan. 2003. Textual Analysis:

A Beginners Guide. London: SAGE Publication 